\title{
EL ESTABLECIMIENTO VIRTUAL Y SU CONDICIÓN DE ESTABLECIMIENTO EMPRESARIAL SECUNDARIO (FILIAL)
}

THE VIRTUAL STORE AND ITS STATUS AS A SECONDARY STORE (OFFICE)

Rubia Carneiro Neves

Professora de Derecho Empresarial de la Universidade Federal de Minas Gerais. Doctora en Derecho Comercial por la Universidade Federal de Minas Gerais.

Ana Caroline Faria Guimarães

Cursa Derecho en la Universidad FUMEC.

Resumen: El presente trabajo analizó la posibilidad de admitirse que un sitio electrónico presente la misma naturaleza jurídica de establecimiento empresarial. En el desarrollo del trabajo, se analizó la exigencia de registro en la Junta Comercial o Notaría de Personas Jurídicas, en el Registro Nacional de Personas Juridicas (CNPJ), en la Receta Estadual y en la Receta Municipal, conforme sea el tipo de actividad, como condición para el ejercicio regular de la actividad económica, lo que presupone necesariamente la información de la sede del empresario, de la sociedad empresaria, de la sociedad simple o de la empresa individual de responsabilidad limitada. Y partiendo de esa exigencia, se desarrolló el análisis sobre el sitio electrónico que pueda ser considerado autónomo o tratarse de una mera extensión del establecimiento empresarial. Se realizó un breve abordaje sobre internet, el comercio electrónico y la web, de modo que fue presentada una sintética referencia cuanto a la historia del surgimiento de la internet, a las ventajas y desventajas del comercio electrónico, así como sobre el funcionamiento internet y de los sitios electrónicos. Se discurrió sobre el concepto y la naturaleza jurídica del establecimiento empresarial, presentando una breve exposición sobre los elementos que integran su composición y se analizó acerca de la posibilidad de encuadrar los sitios electrónicos en la concepción de establecimiento empresarial prevista 
en el art. 1.142, del Código Civil de 2002. El trabajo fue desarrollado utilizándose de la vertiente metodológica jurídico-sociológica, pues, examinó en que medida el cambio de comportamiento ocurrida con la celebración de negocios realizados a través internet viene influenciando en la concepción de establecimiento empresarial. Esa metodología fue escogida, pues se pretendió comprender el fenómeno jurídico de los negocios realizados en el ambiente virtual, admitiendo el Derecho como suscetível de adaptación esos cambios. La dogmática también estuvo presente en el desarrollo del trabajo, pues se analizó y se interpretaron dispositivos legales inherentes a la temática del trabajo. De la misma forma, la vertiente teórico-jurídica fue utilizada en la medida en que el trabajo también se apoyó en la revisión bibliográfica para analizar las teorías que explican la naturaleza jurídica del establecimiento empresarial y del establecimiento virtual.

Palabras clave: Sitios electrónicos. Establecimiento empresarial secundario. Establecimiento virtual. Filial.

Abstract: This study examines the possibility of admitting that an electronic web site has the same legal nature as that of a physical store. In the course of developing the study, the requirement to register at the Trade Board or Corporation Registry, in the Corporate Taxpayer's Registry (CNPJ), and with the State and Municipal Internal Revenue are reviewed, in accordance with the type of activity, as a condition for exercising economic activity, which necessarily presupposes information from the main office of the entrepreneur, the business company, simple corporation, or limited liability company. Based on this requirement, a review is made as to whether the electronic web site could be considered as a standalone or treated merely as an extension of the physical store. A brief overview is given with regard to the Internet, e-commerce, and web sites, which is presented as a synthetic reference to the history of the rise of the Internet, the advantages and disadvantages of e-commerce, and how the Internet and electronic web sites work. The study addresses the concept and legal nature of the store, with a brief statement about the elements that make up its composition, and the possibility of fitting electronic sites into the design of a store is examined, as provided for in Art. 1.142 of the 2002 Civil Code. The work draws from methodological-legal-sociological approaches, as it examines the extent to which behavioural change takes place whenever business is conducted over the Internet and how this has influenced the store's design. This methodology has been chosen because the study intends to understand the legal phenomenon of business being transacted in the virtual environment, assuming that the law as capable of adapting to these changes. Dogmatics is also present as the study is 
developed, as it is used to examine and interpret legal provisions related to its theme. Similarly, a theoretical and legal approach is applied in that the work is also supported in a review of the literature to analyze theories that explain the legal nature of the physical store and the virtual store.

Keywords: Electronic web sites. Secondary store. Virtual store. Office.

\section{INTRODUCCIÓN}

El presente trabajo se propuso a analizar sobre la posibilidad de admitirse que un sitio web presente la misma naturaleza jurídica de establecimiento empresarial.

Al iniciar el desarrollo de ese análisis, se verificó a partir del examen de los conceptos internet, comercio electrónico y sitio electrónico (web) y con fundamento en Marco Aurélio Greco que existen tres especies de webs: pasivos, canalizadores de mensajes e inteligentes.

Examinando las características de esas tres especies de webs, así como del funcionamiento internet y del comercio electrónico, se buscó analizar si la web que presente pompa técnica para interaccionar con el usuario y permitir que a través de él sea realizado el comercio electrónico, deba ser considerado un establecimiento autónomo o una extensión del establecimiento empresarial físico.

En el desarrollo del trabajo, se analizó la exigencia de registro en la Junta Comercial o Notaría de Personas Jurídicas, en el Cadastro Nacional de Personas Juridicas (CNPJ), en la Hacienda Provincial y en la Hacienda Municipal, conforme el tipo de actividad, como condición para el ejercicio regular de la actividad económica, lo que presupone necesariamente la información de la sede del empresario, de la sociedad empresaria, de la sociedad simple o de la empresa individual de responsabilidad limitada. Y partiendo de esa exigencia, se desarrolló el análisis sobre el establecimiento virtual que pueda considerarse autónomo o tratarse de una mera extensión del establecimiento empresarial.

Para desarrollar la reflexión aquí propuesta y responder al problema planteado, se utilizó de la vertiente metodológica jurídico-sociológica, pues, se examinó en qué medida el cambio de comportamiento a partir de la celebración de negocios realizados a través internet ha influenciado en la concepción de establecimiento empresarial. La metodología se justifica por el hecho de pretenderse compreender el fenómeno jurídico de los negocios realizados en el ambiente virtual, admitiéndose el Derecho como suscetível de adaptación a esos cambios. 
El análisis dogmático también estuvo presente en el desarrollo del trabajo, pues fueron analizados dispositivos legales inherentes a la temática del trabajo. De la misma forma, la vertiente teórico-jurídica ha sido adoptada en la medida en que el trabajo también se apoyó en la revisión bibliográfica para analizar concepto internet, de web, de comercio electrónico, así como, las teorías que explican la naturaleza jurídica del establecimiento empresarial y del establecimiento virtual.

El trabajo se dividió en tres partes, siendo la primera realizada un breve abordaje sobre internet, el comercio electrónico y la web, de modo que se examinó una sintética referencia en cuanto a la historia del surgimiento internet, a las ventajas y desventajas del comercio electrónico, así como sobre el funcionamiento internet y de los sitios electrónicos; en la segunda parte, se discurrió sobre el concepto y la naturaleza jurídica del establecimiento empresarial, presentando una breve exposición sobre los elementos que integran su composición, sin analizar la divergencia doctrinaria a ese respeto, justamente por no ser el objetivo propuesto en el presente trabajo; y finalmente, en la tercera, se analizó sobre la posibilidad de clasificar los sitios electrónicos en la concepción de establecimiento empresarial prevista en el art. 1.142, del Código Civil de 2002, sin adentrar en el examen de los demás dispositivos del Código brasileño que tratan del establecimiento, como tampoco se analizó la posibilidad de aplicación de esos dispositivos legales a un sitio web, pues en el trabajo se objetivó investigar tan solamente la posibilidad de admitir el sitio web como establecimiento empresarial.

\section{INTERNET, WEBS Y COMERCIO ELECTRÓNICO: BREVES CONSIDERACIONES}

El presente trabajo busca hacer breves apuntes sobre el surgimiento internet, su concepto y funcionamiento, el comercio electrónico, el concepto y el funcionamiento del sitio web (webs) ${ }^{1}$ en la búsqueda de una mejor comprensión del objeto de estudio.

\subsection{Internet, mundo virtual y webs}

Hubo un tiempo en que las relaciones humanas se limitaban a cortos espacios territoriales, con los pueblos de entonces dedicándose esencialmente a las actividades agrarias. Esa realidad fue siendo paulatinamente alterada en virtud de varios factores, entre ellos, pueden citarse la voluntad por el conocimiento del modo de vida de otras culturas y el desarrollo del comercio como actividad profesional.

1 Aunque la expresión sitio electrónico sea la expresión correcta para la lengua española, se prefirió adoptar en el trabajo tanto la expresión en español cuanto la expresión en inglesa web. 
Anclado a esos factores, los medios de comunicación promovieron la intensificación de las relaciones humanas en locales más distantes, lo que, de hecho, transcurrió de la necesidad de facilitar la relación entre personas situadas en locales geográficamente distantes. Primero advino el telégrafo, después el teléfono, el fax símile, el teléfono celular, hasta que fue desarrollada una red de comunicación, entre ordenadores, que se hizo una red mundial, denominada, internet habiendo promovido una verdadera revolución en el desarrollo de las tecnologías de información y comunicación.

La palabra internet deriva de la expresión en inglés internetwork que significa una interligação entre una red de ordenadores en todo el planeta, habiendo sido creada a partir de la concepción de una red de comunicación establecida entre bases militares norteamericanas durante la Guerra Fría, conocida como ARPANE². Con el final de la Guerra Fría, ese desarrollo dejó de ser un secreto y pasó a ser tratado como una comunidad por los científicos en las universidades de Estados Unidos de América del Norte y posteriormente en universidades de otros países. ${ }^{3}$

La red internet, en continuo desarrollo, comporta la World Wide Web donde es posible crea, almacenar, recuperar, visitar y transferir diversos tipos de archivos, tales como texto, imagen en movimiento, sonidos multimedia. La Web se hace un sistema de comunicación disponible, vía red mundial internet, que permite la creación y comunicación de diversos registros de información o mass medi $\mathrm{y}$ donde se tiene comunicación en hipermídia.

Con un sistema inteligente de localización de archivos, la dirección en internet se hizo individualizado, siendo visitado por cualquier persona. ${ }^{4}$

Pero lo qué es World Wide Web (WWW)? No se confunde con internet. Gustavo Cabecilla Corrêa explica WWW como una convergencia de concepciones relativas a la gran red, o sea, es

el conjunto de patrones y tecnología que posibilitan la utilización internet por medio de

2 FLORESS, Cristian. História da Internet. Disponible en: https://sites.google.com/site/ historiasobreossitesdebusca/historia-da-internet. Acceso en: 19/di/.2012.

3 FLORESS, Cristian. História da Internet. Disponible en: https://sites.google.com/site/ historiasobreossitesdebusca/historia-da-internet. Acceso en: 19/dic./2012.

4 FLORESS, Cristian. História da Internet. Disponible en: https://sites.google.com/site/ historiasobreossitesdebusca/historia-da-internet. Acceso en: 19/12/2012. En el original: “o conjunto de padrões e tecnologia que possibilitam a utilização da internet por meio de programas navegadores, que por sua vez tiram todas as vantagens desse conjunto de padrões e tecnologias pela utilização do hipertexto e suas relações com multimídia, com sons e imagens, proporcionando ao usuário maior facilidade na sua utilização e também a obtenção de melhores resultados" 
programas navegadores, que por su parte quitan todas las ventajas de ese conjunto de patrones y tecnologías por la utilización del hipertexto y sus relaciones con multimedia, con sonidos e imágenes, proporcionando al usuario mayor facilidad en su utilización y también la obtención de mejores resultados. ${ }^{5}$

Francisco Carlos Malosá Júnior ${ }^{6}$ señala que ese conjunto de patrones y tecnología llamado World Wide Web hizo la "cara" internet más simpática, accesible al usuario común.

Ese conjunto, es decir, la World Wide Web fue difundido inicialmente en las universidades americanas, después el uso del mecanismo ha sido permitido en otras universidades del mundo, hasta que hubo también permiso para que personas comunes visitasen la red de ordenadores, a punto de haber 100 webs en $1975 .^{7}$

En 1991, internet surgió en Brasil, con el adviento de la RNP (Red Nacional de Investigación), que era un sistema conectado al MTC (Ministerio de Ciencia y Tecnología). ${ }^{8}$

En 1994, la Embratel lanzó, de forma experimental, el acceso online para ampliar sus ventas en 1995, principalmente, en el área de libros y CDs, siendo pionera el área de librerías: la Librería Cultura. ${ }^{9}$

Hoy, internet se ha presentado con una forma de manifestación de voluntad y de libertad de expresión. Cualquier persona que tiene acceso a ese medio de comunicación y a los conocimientos básicos inherentes a su funcionamiento puede publicar todo tipo de información, reclamación, ideas, expectativas, teorías, frustraciones e ideologías. Como afirma Carlos Alberto Rohrmann "internet es una entidad global: a partir del momento en que una página fue colocada en la red, todo el mundo tiene pleno acceso a ella". ${ }^{10}$

5 CORRÊA, Gustavo Testa. Aspectos jurídicos da internet. 2a . ed. São Paulo: Saraiva, 2002, p. 10 e 11. Apud: MALOSÁ JÚNIOR, Francisco Carlos. A realidade virtual como elemento transformador de estabelecimento empresarial. Anales de lo XVII Encontro Nacional do Conpedi. Salvador: Boiteux, Junio/2008. p.1201.

6 MALOSÁ JÚNIOR, Francisco Carlos. A realidade virtual como elemento transformador de estabelecimento empresarial. Anales de lo XVII Encontro Nacional do Conpedi. Salvador: Boiteux, Junio/2008. p.1201.

7 FLORESS, Cristian. História da Internet. Disponible en: https://sites.google.com/site/ historiasobreossitesdebusca/historia-da-internet. Acceso en: 19/dic./2012.

8 FLORESS, Cristian. História da Internet. Disponible en: https://sites.google.com/site/ historiasobreossitesdebusca/historia-da-internet. Acceso en: 19/dic./2012.

9 IKEDA. Quem somos. Disponible en: <http://www.ikeda.com.br//quem-e-ikeda/>. Según explicitado por la web de la empresa Ikeda: "Pionera en su segmento, Ikeda desarrolló el primero e-commerce brasileño elaborado para la Librería Cultura.” Acceso en: 24/jun./2012.

10 ROHRMANN, Carlos Alberto. O Direito Comercial Virtual - A Assinatura Digital. Revista 
La comprobación de este hecho es el gran número de blogs y páginas existentes en medio virtual. Los internautas utilizan internet para publicar sus impresiones y visiones de mundo, sus emociones, novedades, sus desabafos, principalmente en las famosas redes sociales como el Facebook y el Twitter.

Se percibe que el principio de la libertad de expresión ${ }^{11}$ es el motor de desarrollo internet, además de ser el grande responsable por su crecimiento desde la creación. Más que un derecho, la libertad de expresarse es una proposición elemental y fundamental que sirve de base a la democracia contemporánea en la cual la censura no tiene respaldo moral.

Regis Magalhães Soares de Queiroz explica que en una primera formulación, internet podría ser entendida como un espacio de lugar calificado por no ser físico, pero sí virtual. Reconoce que la Suprema Corte de Estados Unidos afirmó no tratarse de "una entidad física o tangible, pero una enorme red de ordenadores (network) que interliga incontables pequeños grupos de redes de ordenadores (networks) por su parte interconectados. Puede definirse como una red de redes de ordenadores." 12

El autor admite la importancia de esa concepción que, inclusive, ha sido adoptada en la definición técnica internet por la alínea el ítem 3, de la Norma 004/95, aprobada pela Portaría n. 148, de 31/5/95, del Ministerio de las Comunicaciones de Brasil: "nombre genérico que designa el conjunto de redes, los medios de transmisión y conmutación, roteadores, equipamientos y protocolos necesarios a la comunicación entre ordenadores, así como el software y los datos contenidos en estos ordenadores." 13

Pero, para él, internet es mucho más que una red de ordenadores.

da Faculdade de Direito Milton Campos. Belo Horizonte: Del Rey, 1997. v. 4, p. 33.

11 El principio de la libertad de expresión es un derecho fundamental, protegido por la Constitución, siendo considerado un marco importante para la democracia, no sólo de Brasil, pero de diversos otros países. Puede ser caracterizado como derecho de personalidad, fundamental para la concretización del principio de la dignidad de la persona humana. Ese principio permite la manifestación libre de gana, opiniones, pensamientos e ideas. El artículo 19 de la Declaración Universal de los Derechos Humanos de 1948 lo define como "la libertad para transmitir informaciones e ideas por cualesquier medios independientemente de fronteras". Además del más, tiene como marco fundamental, el control de la actividad gubernamental y del propio ejercicio del poder, evitando la ocurrencia de la censura, que es la supressão del Estado democrático de derecho.

12 QUEIROZ, Regis Magalhães Soares. Vedação da concorrência do trepassante do estabelecimento empresarial: seus limites e sua aplicação no espaço real e virtual. 185 f. Disertación (Máster en Derecho) - Faculdade de Direito, Universidade de São Paulo, São Paulo. 2000. p. 147.

13 Disponible en: http://legislacao.anatel.gov.br/normas-do-mc/78-portaria-148. Acceso en: $15 / \mathrm{abr} . / 2014$. 


\section{Regis Magalhães Soares Queiroz considera internet como}

metaterritório - trascendente en relación al
territorio físico porque creado virtualmente
por medio de maciza interligação de redes de
ordenadores esparcidos por el mundo que, por
lo tanto, no conocen fronteras físicas -, donde
es posible todo tipo de información, por la
transferencia de archivos de ordenador para
ordenador, utilizando los medios y la infraestrutura
de comunicación disponibles y de esa forma, el
usuario puede relacionarse así como establecer
toda suerte de relaciones jurídicas y sociales. ${ }^{14}$

\section{Pierre Lévy explica la noción de virtual, diciendo que}

es virtual toda entidad 'desterritorializada', capaz de generar diversas manifestaciones concretas en diferentes momentos y locales determinados, sin, contundo estar ella misma presa a un lugar o tiempo en particular. Para usar un ejemplo fuera de la esfera técnica, una palabra es una entidad virtual. El vocablo 'árbol' está siempre siendo pronunciado en un local u otro, en determinado día en una cierta hora. Llamaremos la enunciação de este elemento lexical de 'actualización'. Pero la palabra en sí, aquella que es pronunciada o actualizada en un cierto lugar, no está en lugar ninguno y no se encuentra a ningún momento en particular (aunque ella no haya existido desde siempre). Repitiendo, aunque no podamos fijarlo en ninguna coordenada espacio-territorial, el virtual es real. Una palabra existe de hecho. El virtual existe sin estar presente ${ }^{15}$

14 QUEIROZ, Regis Magalhães Soares. Vedação da concorrência do trepassante do estabelecimento empresarial: seus limites e sua aplicação no espaço real e virtual. 185 f. Disertación (Máster en Derecho) - Faculdade de Direito, Universidade de São Paulo, São Paulo. 2000. p. 152. En el original: "metaterritório - transcendente em relação ao território físico porque criado virtualmente por meio de maciça interligação de redes de computadores espalhados pelo mundo que, portanto, não conhecem fronteiras físicas -, onde é possível todo tipo de informação, pela transferência de arquivos de computador para computador, utilizando os meios e a infraestrutura de comunicação disponíveis e dessa forma, o usuário pode se relacionar bem como estabelecer toda sorte de relações jurídicas e sociais."

15 LÉVY, Pierre. Cibercultura. São Paulo: Editora 34, 2000, p.47. Em el original: "é virtual toda entidade 'desterritorializada', capaz de gerar diversas manifestações concretas em diferentes momentos e locais determinados, sem, contundo estar ela mesma presa a um lugar 
Según el diccionario Houaiss de la Lengua Portuguesa, el virtual ${ }^{16}$ tiene por existencia sólo en potencia o en facultad, no como realidad o con efecto real. Sin embargo, el hecho de no estar en lugar físico no caracteriza su "no existencia". Así como el hecho de la información o el dato situarse en algún espacio no designável, no le quita la existencia.

Lo que es virtual existe y es real, puede ser desproveído de presencia material, pero existe en potencia, o sea, es revelado por medio de una constante actualización, confiriendo sólo dos posibilidades: ser, o no, realizado. Es también una posibilidad o tendencia presentada por cualquier realidad material en el sentido de modificarse o ser modificada, de tal forma que ella pueda perfazer todas las determinaciones que aún se mantiene sólo virtuales.

El sitio web o web, objeto de investigación de este trabajo, está localizado en ese metaterritório, por tanto virtual, pero es tan real cuanto se estuviera localizado en cualquier lugar físico. También conocido como website es formado por un conjunto de páginas web, es decir, hipertextos generalmente accesibles en internet por el protocolo HTTP (HyperText Transfer Protocol - Protocolo de Transferencia de Hipertexto $)^{17}$, siendo que el conjunto de todas las webs públicas existentes compone World Wide Web.

Las páginas de una web son organizadas a partir de un URL (Uniform Resource Locator - Localizador Uniforme de Recursos) básico, donde se pone la página principal, y generalmente residen en el mismo directorio de un servidor. Las páginas son organizadas dentro de la web en una jerarquía en contexto URL, aunque los hiperlinks entre ellas controlen el modo como el lector se aproxima de la estructura global, modo ese que puede tener poca relación con la estructura jerárquica de los archivos de la web.

\subsection{Comercio electrónico}

Principalmente a través de la utilización de esas webs es que

ou tempo em particular. Para usar um exemplo fora da esfera técnica, uma palavra é uma entidade virtual. O vocábulo 'árvore' está sempre sendo pronunciado em um local ou outro, em determinado dia numa certa hora. Chamaremos a enunciação deste elemento lexical de 'atualização'. Mas a palavra em si, aquela que é pronunciada ou atualizada num certo lugar, não está em lugar nenhum e não se encontra a nenhum momento em particular (ainda que ela não tenha existido desde sempre). Repetindo, ainda que não possamos fixá-lo em nenhuma coordenada espaço-territorial, o virtual é real. Uma palavra existe de fato. O virtual existe sem estar presente."

16 Houaiss, Antônio. Diccionario Electrónico Houaiss de la Lengua Portuguesa. Rio de Janeiro: FL Gama Design Ltda Editora Objetiva, 2009.

17 Eckersley, Peter. Encrypt the Web with the HTTPS Everywhere Firefox Extension. Estados Unidos: EFF. 17/06/2010. Apud: Tatsch, Fabiano. Discussão: HTTP. 26/may./ 2011. 
se realiza el comercio electrónico o e-commerce. También conocido como comercio virtual, surgió con la evolución internet, con el objetivo de complementar el proceso de ventas y eliminar intermediarios en la actividad de compraventa y venta de mercancías y de prestación de servicios, en aras de auxiliar en la globalización de la economía a través de la realización de asociaciones, negocios y disminución de límites geográficos.

El comercio electrónico no debe confundirse con la definición internet, pues ella representa el medio por lo cual se desarrolla ese comercio. Podemos conceituar el comercio electrónico como el conjunto de transacciones comerciales realizadas por medio de un ordenador, ${ }^{18}$ pudiendo abarcar la venta de productos o la prestación de servicios que ocurren a través del medio virtual. La naturaleza del servicio prestado o del bien no es relevante para la definición de comercio electrónico. En este sentido, Fábio Ulhoa Coelho assevera:

comercio electrónico es la venta de productos (virtuales o fisicos) o la prestación de servicios en que la oferta y el contrato son hechos por transmisión y recepción electrónica de datos. El comercio electrónico se realiza en el ambiente de la red mundial de ordenadores. ${ }^{19}$

\section{La Australian Reports and Analysis Centre (AUSTRAC) conceitua comercio electrónico como:}

un término general aplicado al uso del ordenador y tecnologías de las Telecomunicaciones, particularmente en una base inter-empresarial, desde el comercio de bienes y servicios. El Comercio Electrónico usa una variedad de tecnologías tales como EDI, E-mail, transferencia por fax, catálogos electrónicos [...]. La creación y la gerencia de la relación entre compradores $y$ vendedores, facilitada por un medio interactivo $y$ persuasivo. ${ }^{20}$

18 Disponible en: http://www.decisoes.com.br/v29/imprimir_conteudo.php?user=\&id_ conteudo=108277. Acceso en: 15/abr. $/ 2014$.

19 COELHO, Fábio Ulhoa. Curso de direito comercial. v. 3. São Paulo: Saraiva, 2012. p. 48. En el original: "comércio eletrônico é a venda de produtos (virtuais ou físicos) ou a prestação de serviços em que a oferta e o contrato são feitos por transmissão e recepção eletrônica de dados. O comércio eletrônico realiza-se no ambiente da rede mundial de computadores."

20 En el original: Um termo geral aplicado ao uso do computador e tecnologias das Telecomunicações, particularmente em uma base inter-empresarial, desde o comércio de bens e serviços. O Comércio Eletrônico usa uma variedade de tecnologias tais como EDI, E-mail, 
La Organización Mundial del Comercio (OMC), en programas de trabajo del año de 1998, presentó su definición sobre el comercio electrónico que consiste en la "producción, distribución, propaganda, venta o entrega de bienes y servicios por medios electrónicos". ${ }^{21}$

En el comercio electrónico, pueden negociarse productos virtuales o físicos. Son virtuales productos como los periódicos electrónicos, los libros digitales, el download de programas, o sea, aquellos colocados a la disposición del adquirente de forma inmaterial, en disponibilidad electrónica, por medio de transmisión de datos para un ordenador. Mientras que los productos físicos, obviamente, son aquellos materializados, tales como televisores, refrigeradores, ordenadores, ropas, entre otros.

Además de productos virtuales y físicos, el medio electrónico permite la contratación de servicios, cuya ejecución también puede ocurrir en medio virtual, como, por ejemplo, el homebanking, a través del cual las instituciones financieras colocan a la disposición de sus clientes, a través de sus webs, servicios bancarios como transferencias de valores, pedidos de chequeras, operaciones con tarjeta de crédito, además del pago de gastos y seguimiento de cuentas corrientes, de ahorro o de inversión.

En gran medida, el comercio electrónico mejoró la realización de negocios de las organizaciones empresariales una vez que facilitó el proceso de negociación, aumentando el número de los acuerdos cerrados, haciendo en muchos casos, la venta más rápida, más práctica, además de la perspectiva de reducción de costes con estimulo a la competitividad. Además, incrementó la facilidad de contactos con los clientes, proveedores y distribuidores, lo que de cierta manera propició mejorías en el nivel de comunicación entre la organización empresarial y el mercado consumidor.

Las herramientas del comercio electrónico están en constante perfeccionamiento, pero la compraventa de un producto con pago por medio de tarjeta de crédito o cajero o en cualquiera otro medio digital, ya se caracteriza como un negocio realizado vía medio electrónico, lo que lleva a la conclusión de que el comercio electrónico no creó un nuevo tipo de comercio, sino que aprovechó nuevas tecnologías de la informática y de la comunicación para realizar las tareas tradicionales de compraventas y venta.

Olavo Baptista compara el comercio electrónico con la actividad del mascate que no poseía un establecimiento fijo, cuyos contratos eran

transferência por fax, catálogos eletrônicos [...]. A criação e a gerência do relacionamento entre compradores e vendedores, facilitada por um meio interativo e persuasivo. In: CANELLA, Sergio Eduardo; LEWIS, Sandra Barbon. Breves Anotações sobre o Comércio Eletrônico. Londrina: Scientia Iuris. v. 9, p. 299-316, 2005.

21 Disponible en: <WWW.wto.org>. Acceso en: 12/jun./2012. 
orales:

el comercio electrónico es, de cierta forma, lo retorno del mascate. Todos nosotros tenemos el recuerdo de este personaje, frecuente en los tiempos coloniales, aún existente en el inicio del siglo XX, y que visitaba la casa de las personas en la zona rural o en los barrios alejados, llevando mercancías de pequeño porte, e imágenes o muestras de otras que entregaría cuando encomendadas por el comprador interesado. El mascate no tenía establecimiento propio. Iba hasta el comprador, y le ofrecía bienes que, en gran medida, no tenía en stock y adquiría para entregar, cuando encomendados. La especificidad de la actividad comercial del mascate era a de desplazarse delante del consumidor final y ofrecerle, verbalmente, la mercancía, eliminando la necesidad de desplazamientos fisicos de este, proponiéndole una variedad de bienes. ${ }^{22}$

Son bastante amplios las ventajas del comercio electrónico como: expansión de los negocios, mayor comodidad para el cliente, la red de tiendas estará disponible 24 horas, seguridad y rapidez en el pago de las mercancías, economía de tiempo, posibilidad de descuento mayor en el precio del producto con la consecuente disminución del coste de contratación de vendedores y sin repase de comisiones a los mismos. Igualmente, consigue clientes localizados en regiones geográficamente distantes. No hay necesidad de alquilar una tienda física e invertir en decoración, escaparates, entre otros ítems. Permite aumentar la tasa de lucratividad de la organización empresarial, ofrece bajo tiempo de entrega del producto encargado, posibilita una mejor investigación de precio del producto, rapidez en la divulgación de nuevos productos o promociones, reducción de la mano de obra, comercialización en

22 BAPTISTA, Luiz Olavo. Comércio Eletrônico: Uma Visão do Direito Brasileiro, Revista da Faculdade de Direito da Universidade de São Paulo. V.94, São Paulo: Serviço Técnico de Imprensa da Faculdade de Direito da Universidade de São Paulo, 1999. p.85-86. En el original: "o comércio eletrônico é, de certa forma, o retorno do mascate. Todos nós temos a lembrança deste personagem, frequente nos tempos coloniais, ainda existente no início do século XX, e que visitava a casa das pessoas na zona rural ou nos bairros afastados, levando mercadorias de pequeno porte, e imagens ou amostras de outras que entregaria quando encomendadas pelo comprador interessado. $\mathrm{O}$ mascate não tinha estabelecimento próprio. Ia até o comprador, e oferecia-lhe bens que, em grande parte, não tinha em estoque e adquiria para entregar, quando encomendados. A especificidade da atividade comercial do mascate era a de se deslocar diante do consumidor final e oferecer-lhe, verbalmente, a mercadoria, eliminando a necessidade de deslocamentos físicos deste, propondo-lhe uma variedade de bens." 
ámbito global, etc.

En suma, todas las exigencias tradicionales de enormes inversiones, gastos fijos, instalaciones físicas, coste de mano de obra, marketing, fondo de comercio, pueden acortarse o simplemente suprimirse.

Entre las desventajas descritas, la falta de seguridad en algunas webs se presenta como una gran traba al buen funcionamiento del comercio electrónico. Muchas veces, la dificultad de identificación real de los responsables por las webs viabiliza la práctica del llamado delito virtual. Sin embargo, el dispuesto en el artículo $2^{\circ}$, II, del Decreto Ley 7.962 de 2013 pasa a obligar que las casas de campo electrónicas o demasiado medios electrónicos utilizados para oferta o conclusión de contrato de consumo, disponibilizem de forma clara y visible, la dirección física y electrónico, y demasiado informaciones necesarias para su localización y contacto. De esa forma, la norma comienza a regularizar las relaciones que envuelven el medio virtual, dificultando la práctica de delitos.

No es el caso de la Apelación Civil, $n^{0}$ 70026683938, proveniente de la comarca de Porto Alegre, juzgada por el Tribunal de Justicia de Rio Grande do Sul; o sea, en ese proceso no hubo problema de identificación del proveedor que actuó en medio electrónico, pero el caso traduce un ejemplo de problema que puede resultar directamente del comercio electrónico. El Tribunal condenó por daño moral la responsable por el suministro que vendió productos por la internet y procedió al lanzamiento del cobro en duplicidad en la tarjeta de crédito de la consumidora:

APELACIÓN CÍVEL. RESPONSABILIDAD CIVIL. COMERCIO ELECTRÓNICO. COMPRAVENTA $Y$ VENTA POR LA INTERNET. ERROR. COBRO DUPLICE EN LA FACTURA DE LA TARJETA DE CRÉDITO. ATENCIÓN ONLINE. DESCASO CON El CONSUMIDOR. DAÑO MORAL. QUANTUM INDENIZATÓRIO. CRITERIOS.Supera el mero dissabor la situación de los autos en que la autora, al adquirir productos por la internet, hubo lanzado en duplicidad los valores en su tarjeta de crédito. Diversos contactos entre el consumidor y el proveedor sin que la dificultad fuera solucionada. Descaso con el consumidor verificado. Cese del cobro alcanzado sólo mediante acción judicial. Daño moral caracterizado. Valor de la condena fijado de acuerdo con las peculiaridades del caso concreto, especialmente considerando los 
principios de la proporcionalidad y razoabilidade, además de la naturaleza jurídica de la obligación. ${ }^{23}$

Otro caso específico de problema que puede transcurrir del comercio electrónico es lo del siguiente Fallo de la Tercera Turma del STJ, referente a la compraventa y venta de producto hecho por la internet

CIVIL Y COMERCIAL. COMERCIO ELECTRÓNICO. WEB VUELTA PARA LA INTERMEDIACIÓNDE VENTA Y COMPRAVENTA DE PRODUCTOS. VIOLACIÓN DE MARCA. INEXISTENCIA.PRINCIPIODELEXAURIMENTO DE LA MARCA. APLICABILIDADE. NATURALEZA DEL SERVICIO. PROVEDORIA DE CONTENIDO. PREVIA FISCALIZACIÓN DEL ORIGEN DE LOS PRODUCTOS ANUNCIADOS. DESNECESSIDADE. RIESGO NO INHERENTE AL NEGOCIO. CIENCIA DE LA EXISTENCIA DE VIOLACIÓN DE PROPIEDAD INDUSTRIAL. REMOCIÓN INMEDIATA DEL ANUNCIO. DEBER. DISPONIBILIZAÇÃO DE MEDIOS PARA IDENTIFICACIÓN DE CADA USUARIO. DEBER. 1. El art. 132, III, de la Ley $n^{\circ} 9.279 / 96$ consagra el principio del exaurimento de la marca, con base en el cual queda el titular de la marca impossibilitado de impedir la circulación (revenda) del producto, inclusive por medios virtuales, después de este haber sido regularmente introducido en el mercado nacional. 2. El servicio de intermediación virtual de venta y compraventa de productos caracteriza una

23 TJRS - 9a Câm. Cível; ACi no 70031676919-Porto Alegre-RS; Rel. Des. Tasso Caubi Soares Delabary; j.9/12/2009; m.v. BAASP, 2678/1835-e, de 3.5.2010. En el original: “APELAÇÃO CÍVEL. RESPONSABILIDADE CIVIL. COMÉRCIO ELETRÔNICO. COMPRA E VENDA PELA INTERNET. ERRO. COBRANÇA DUPLICE NA FATURA DO CARTÃO DE CRÉDITO. ATENDIMENTO ON LINE. DESCASO COM O CONSUMIDOR. DANO MORAL. QUANTUM INDENIZATÓRIO. CRITÉRIOS. Supera o mero dissabor a situação dos autos em que a autora, ao adquirir produtos pela internet, teve lançado em duplicidade os valores em seu cartão de crédito. Diversos contatos entre o consumidor e o fornecedor sem que o impasse fosse solucionado. Descaso com o consumidor verificado. Cessação da cobrança atingida apenas mediante ação judicial. Dano moral caracterizado. Valor da condenação fixado de acordo com as peculiaridades do caso concreto, especialmente considerando os princípios da proporcionalidade e razoabilidade, além da natureza jurídica da obrigação." 
especie del género provedoria de contenido, pues no hay edición, organización u otra forma de gestión de las informaciones relativas a las mercancias insertadas por los usuarios. 3. No se puede imponer a las webs de intermediación de venta y compra la previa fiscalización sobre el origen de todos los productos anunciados, en la medida en que no constituye actividad intrínseca al servicio prestado. 4. No se puede, bajo el pretexto de dificultar la propagación de contenido ilícito u ofensivo en la web, reprimir el derecho de la coletividad a la información. Sopesados los derechos envueltos y el riesgo potencial de violación de cada uno de ellos, el fiel de la balanza debe pender para la garantía de la libertad de información asegurada por el art. 220 , $\S 1^{\circ}$, de la $C F / 88$, sobre todo considerando que internet representa, hoy, importante vehículo comunicacional social de masa. 5. Al ser comunicado de la existencia de oferta de productos con violación de propiedad industrial, debe el intermediador virtual de venta y compra actuar de forma enérgica, removiendo el anuncio de la web inmediatamente, bajo pena de responder solidariamente con el autor directo del daño, en virtud de la omissão practicada. 6. Al ofertar un servicio virtual por medio del cual se posibilita el anuncio para venta de los más variados productos, debe lo intermediador tener el cuidado de propiciar medios para que se pueda identificar cada uno de los usuarios, a fin de que eventuales ilícitos no encalan en el anonimato. Bajo la ótica de la diligencia media que se espera de ese intermediador virtual, debe este adoptar las providencias que, conforme las circunstancias especificas de cada caso, estén a su alcance para la individualização de los usuarios de la web, bajo pena de responsabilización subjetiva por culpa in omittendo. 7. Recurso especial a que se niega provimento. ${ }^{24}$

24 STJ - $3^{\text {a Turma; REsp no } 1383354-S a ̃ o ~ P a u l o-S P ; ~ R e l a t o r ~(a): ~ M i n i s t r a ~ N a n c y ~ A n d r i g h i ; ~ d a t a ~}$ julagmento: 27/08/2013; publicação: 26/09 /2013. En el original: "CIVIL E COMERCIAL. COMÉRCIO ELETRÔNICO. SITE VOLTADO PARA A INTERMEDIAÇÃO DE VENDA E COMPRA DE PRODUTOS. VIOLAÇÃO DE MARCA. INEXISTÊNCIA. PRINCÍPIO DO EXAURIMENTO DA MARCA. APLICABILIDADE. NATUREZA DO SERVIÇO. PROVEDORIA DE CONTEÚDO. PRÉVIA FISCALIZAÇÃO DA ORIGEM 
A continuación, la ementa transcrita, también describe un caso de falta de seguridad al adquirir productos por medios electrónicos

PRESTACIÓN DE SERVICIOS DE COMERCIO
ELECTRÓNICO ACCIÓN DE RESTITUCIÓN DE
VALOR PAGADO C.C. INDEMNIZACIÓN POR
DAÑOS MORALES Y MATERIALES. Empresa que
suministra ambiente electrónico e intermediación
para negocios de compraventas y venta por
la internet. Relación de consumo configurada.
Confianza y seguridad en el ambiente suministrado
por la empresa que no bastaron para evitar el
perjuicioala autora. Daños morales. Indemnización
debida-Acción parcialmente procedente. Sentencia
mantenida. Recurso desprovido.

DOS PRODUTOS ANUNCIADOS. DESNECESSIDADE. RISCO NÃO INERENTE AO NEGÓCIO. CIÊNCIA DA EXISTÊNCIA DE VIOLAÇÃO DE PROPRIEDADE INDUSTRIAL. REMOÇÃO IMEDIATA DO ANÚNCIO. DEVER. DISPONIBILIZAÇÃO DE MEIOS PARA IDENTIFICAÇÃO DE CADA USUÁRIO. DEVER. 1. O art. 132, III, da Lei $n^{\circ} 9.279 / 96$ consagra o princípio do exaurimento da marca, com base no qual fica o titular da marca impossibilitado de impedir a circulação (revenda) do produto, inclusive por meios virtuais, após este haver sido regularmente introduzido no mercado nacional. 2. O serviço de intermediação virtual de venda e compra de produtos caracteriza uma espécie do gênero provedoria de conteúdo, pois não há edição, organização ou qualquer outra forma de gerenciamento das informações relativas às mercadorias inseridas pelos usuários. 3. Não se pode impor aos sites de intermediação de venda e compra a prévia fiscalização sobre a origem de todos os produtos anunciados, na medida em que não constitui atividade intrínseca ao serviço prestado. 4. Não se pode, sob o pretexto de dificultar a propagação de conteúdo ilícito ou ofensivo na web, reprimir o direito da coletividade à informação. Sopesados os direitos envolvidos e o risco potencial de violação de cada um deles, o fiel da balança debe pender para a garantia da liberdade de informação assegurada pelo art. $220, \S 1^{\circ}$, da $\mathrm{CF} / 88$, sobretudo considerando que a Internet representa, hoje, importante veículo de comunicação social de massa. 5 . Ao ser comunicado da existência de oferta de produtos com violação de propriedade industrial, deve o intermediador virtual de venda e compra agir de forma enérgica, removendo o anúncio do site imediatamente, sob pena de responder solidariamente com o autor direto do dano, em virtude da omissão praticada. 6. Ao oferecer um serviço virtual por meio do qual se possibilita o anúncio para venda dos mais variados produtos, deve o intermediador ter o cuidado de propiciar meios para que se possa identificar cada um dos usuários, a fim de que eventuais ilícitos não caiam no anonimato. Sob a ótica da diligência média que se espera desse intermediador virtual, deve este adotar as providências que, conforme as circunstâncias específicas de cada caso, estiverem ao seu alcance para a individualização dos usuários do site, sob pena de responsabilização subjetiva por culpa in omittendo. 7. Recurso especial a que se nega provimento."

25 TJSP - 35 Câmara de Direito Privado; APL 0000756-92.2012.8.26.0097-São PauloSP; Relator (a): Melo Bueno; data julagmento: 10/06/2013; publicação: 11/06 /2013. 
No obstante, la existencia de esas desventajas, la utilización del medio electrónico para la concretización de la venta de productos y la prestación de servicios se incrementa a cada día, y se ha mostrado como una excelente estrategia de realización de negocios. ${ }^{26}$

Delante de esa realidad, se confirma la máxima según la cual, primero surgen los fenómenos sociales para después crear el Derecho apto a reglamentarlos. En el caso del comercio electrónico, hay una serie de cuestiones jurídicas que merecen examen, entre ellas, la posibilidad de el sitio web ser o no caracterizado como establecimiento empresarial y si las reglas de este instituto pueden aplicarse indistintamente al sitio web.

Antes de concluir sobre tal cuestión, se deberá de presentar el concepto, las características y los elementos del establecimiento empresarial físico para después realizar el análisis comparativo de esos aspectos con los de el sitio web.

Sobre el comercio electrónico es importante hacer una observación sobre el funcionamiento del comercio electrónico cuando tratarse de la relación de consumo, como el caso de las compras hechas por el consumidor a través de la internet. El Código de Defensa del Consumidor, Ley 8.078 de 1990, no hacía ninguna mención específica sobre compraventa y Vanda por medio de la internet. Para sanar ese vacío, fue creado el Decreto Ley 7.962 de 2013, pela presidente Dilma Rousseff, que pasó a reglamentar el Código de Defensa del Consumidor, trayendo las normas para el comercio electrónico.

De entre las importantes determinaciones traídas, esas son las principales

Las tiendas virtuales están obligadas la disponibilizar en local de fácil visualización en su página, todos sus datos, tales como: el nombre empresarial, número de inscripción siendo el CNPJ o CPF para los casos de venta por persona física y dirección de donde está localizada la tienda u oficina de la empresa. También es factor

En el original: "PRESTAÇÃO DE SERVIÇOS DE COMÉRCIO ELETRÔNICO AÇÃO DE RESTITUIÇÃO DE VALOR PAGO C.C.INDENIZAÇÃO POR DANOS MORAIS E MATERIAIS. Empresa que fornece ambiente eletrônico e intermediação para negócios de compra e venda pela internet. Relação de consumo configurada. Confiança e segurança no ambiente fornecido pela empresa que não bastaram para evitar o prejuízo à autora. Danos morais. Indenização devida - Ação parcialmente procedente. Sentença mantida. Recurso desprovido.”

26 Disponible en: http://www.pbagora.com.br/conteudo.php?id=20120715091332\&cat=para iba\&keys=cresce-numero-empresas-vendem-produtos-servicos-pela-internet. Acceso en: 09/ mar./2013. 
relevante atentar que la regla aún es ignorada por la mayoría de las tiendas virtuales en el país. La situación aún se agrava cuando hablamos sobre la obligación que la tienda tiene que suministrar todas las características esenciales del producto o del servicio que está ofertando, incluyendo posibles riesgos a la salud que este pueda venir a causar y rango etária permitida para uso. La nueva reglamentación exige que los anuncios discriminem de forma clara el precio, coste del frete o cobro de seguro, así como las condiciones integrales de la oferta constando las modalidades de pago, disponibilidad, plazo para ejecución del servicio o para la entrega del producto. Pasó a ser obligatorio, aunque la empresa presente el contrato de compraventa o de suministro de servicio en el momento en que el cliente hace el pedido, teniendo este contrato que quedar disponible para consulta a cualquier tiempo por el consumidor después de la compraventa. Otra exigencia bastante importante está en la cuestión de la atención al cliente. Con el decreto, las empresas pasan a tener que responder cualquier solicitud del consumidor con una respuesta satisfactoria dentro de hasta 05 dias. ${ }^{27}$

\section{ESTABLECIMIENTO EMPRESARIAL: CONCEPTO Y NATURALEZA JURÍDICA}

Aún en la época en que prevalecía la teoría de los actos de comercio en Brasil, João Eunápio Borges ya admitía que para el ejercicio del comercio, cualquier emprendedor necesita de capital, trabajo y organización. ${ }^{28}$ Ineludiblemente el emprendedor de actividades económicas reúne un conjunto de bienes materiales e inmateriales de forma organizada que restó definido por el Código Civil de 2002 como siendo establecimiento.

El art. 1.142, del Código Civil de 2002 de Brasil define establecimiento como todo complejo de bienes organizado, para ejercicio de la empresa, por empresario, o por sociedad empresaria.

Para Rubens Requião, el establecimiento es un bien móvil,

27 Disponible en: http://philipemcardoso.jusbrasil.com.br/artigos/113493141/conheca-seusdireitos-com-as-novas-normas-de-compra-pela-internet?ref=home Acceso en: 15/abr./2014.

28 BORGES, João Eunápio. Curso de Direito Comercial Terrestre. Rio de Janeiro: Forense, 1971, p.184-185. 
incorpóreo, constituido de "un complejo de bienes que no se funden, pero mantiene unitariamente su individualidad propia". Trasciende a la mera suma de los diversos bienes que lo compone, consistiendo en un sobrevalor (igual más-valía) que aumenta el valor individual atribuido a cada uno de los bienes que el compone. ${ }^{29}$

Fábio Ulhoa Coelho explica que establecimiento empresarial

"es el conjunto de bienes que el empresario reúne para explotación de su actividad económica. Comprende los bienes indispensables o útiles al desarrollo de la empresa, como las mercancías en stock, máquinas, vehículos, marca y otras señales distintivas, tecnología etc. Se trata de elemento indisociable a la empresa. No existe como dar inicio a la explotación de cualquier actividad empresarial, sin la organización de un establecimiento." 30

El autor hace una analogía entre establecimiento y una biblioteca y explica que en ella, no hay sólo libros agrupados al acaso, pero un conjunto de libros sistemáticamente reunidos, dispuestos organizadamente, con una finalidad - posibilitar el acceso racional a determinado tipo de información. Una biblioteca tiene el valor comercial superior a lo de la simple suma de los precios de los libros que la componen, justamente en razón de ese aspecto, es decir, de esa organización racional de las informaciones contenidas en los libros reunidos. ${ }^{31}$ Así también se puede analizar el establecimiento, pues posee un valor normalmente superior al valor individual de los bienes que lo componen.

Sobre la naturaleza jurídica del establecimiento empresarial, Fábio Ulhoa Coelho destaca tres puntos esenciales, al señalar que (i) el establecimiento empresarial no es sujeto de derecho. El sujeto de derecho es el empresario, titular del establecimiento y este no posee personalidad jurídica; (ii) el segundo aspecto, se refiere a la consideración según la cual el establecimiento empresarial es una cosa; (iii) y el tercero se refiere al hecho de que el establecimiento empresarial

29 REQUIÃO, Rubens. Curso de Direito Comercial. São Paulo: Saraiva, 2007. p. 276.

30 COELHO, Fábio Ulhoa. Curso de direito comercial. v. 1. São Paulo: Saraiva, 2012, p. 96. En el original: "é o conjunto de bens que o empresário reúne para exploração de sua atividade econômica. Compreende os bens indispensáveis ou úteis ao desenvolvimento da empresa, como as mercadorias em estoque, máquinas, veículos, marca e outros sinais distintivos, tecnologia etc. Trata-se de elemento indissociável à empresa. Não existe como dar início à exploração de qualquer atividade empresarial, sem a organização de um estabelecimento.”

31 COELHO, Fábio Ulhoa. Manual de Direito Comercial. $17^{\mathrm{a}}$ ed. São Paulo: Saraiva, 2006, p. 56 . 
integra el patrimonio del empresario o de la sociedad empresaria. El establecimiento no puede confundirse con el empresario o la sociedad empresaria (sujeto de derecho), ni con la empresa (actividad económica organizada u organización de factores de producción). ${ }^{32}$

El Código Civil brasileño de 2002, en el art. 90, prescribe que "constituye universalidad de hecho la pluralidad de bienes singulares que, pertinentes a la misma persona, tengan destinación unitaria" y en el art. 91, que "constituye universalidad de derecho el complejo de relaciones jurídicas, de una persona, dotadas de valor económico".

Marcelo M. Bertoldi y Marcia Carla Pereira Ribeiro entienden que el establecimiento es una universalidad de derecho porque pasó a ser definido por el art. 1.142 del Código Civil. ${ }^{33}$

En otro contexto, Sérgio Campinho explica que no se puede admitir el establecimiento como una universalidad de derecho porque no tiene su existencia derivada de la ley. "No se constituye, como la herencia y la masa falida, por ejemplo, por fuerza de ley, pero en razón de la voluntad del empresario.'

Y continúa él, afirmando que

por tal motivo es que la doctrina ha convergido en la opinión de que el establecimiento empresarial se constituye en una universalidad de hecho (universitas facti). Es un complejo de bienes, cada cual con individualidad propia, con existencia autónoma, pero que, en razón de la simple gana de su titular, se encuentran organizados para la explotación de la empresa, formando, así, una unidad, adquiriendo un valor patrimonial por su todo. $^{34}$

Con idéntica opinión, se pronuncia Fran Martins, diciendo que el establecimiento es una universalidad de hecho, "o sea, un conjunto de cosas distintas, con individualidad propia, que se transforman en un

32 Idem, Ibidem, p. 99.

33 BERTOLDI, Marcelo M. RIBEIRO, Marcia Carla Pereira. Curso avançado de Direito Comercial. 6. ed. rev. atual. São Paulo: Revista dos Tribunais, 2011, p. 98.

34 CAMPINHO, Sérgio. O direito de empresa à luz do novo Código Civil. 5. ed. ampl. atual. Rio de Janeiro: Renovar, 2005, p. 300-301. En el original: "por tal motivo é que a doutrina tem convergido na opinião de que o estabelecimento empresarial constitui-se em uma universalidade de fato (universitas facti). É um complexo de bens, cada qual com individualidade própria, com existência autônoma, mas que, em razão da simples vontade de seu titular, encontramse organizados para a exploração da empresa, formando, assim, uma unidade, adquirindo um valor patrimonial pelo seu todo." 
todo por la voluntad del comerciante." 35

En el mismo sentido es la posición de Alfredo de Assis Gonçalves Neto, para quien establecimiento empresarial tiene la misma naturaleza jurídica de universalidad de hecho. Explica el autor que

la distinción entre universalidad de hecho y de derecho estaría en que la primera sería una reunión de bienes, como el rebaño y la biblioteca, mientras que la segunda sería un agregado de derechos, como la herencia, la masa falida etc. En la universalidad de hecho el conjunto de cosas singulares, simples o compuestas, resulta de la gana de la persona que les da la destinación común que mejor le aprouver. Ya en la universalidad de derecho, hay un complejo de relaciones de derecho la que la orden jurídica atribuye carácter unitario. Es en ese sentido que se deben comprender los enunciados de los arts. 90 y 91 del Código Civil de 2002. Como conjunto de bienes afectados al ejercicio de la empresa, tal como definido en el art. 1.142 del Código Civil, el establecimiento es una universalidad de hecho. ${ }^{36}$

Asumimos la posición teórica de que el establecimiento es una universidad de hecho (universitas facti). Y tiene razón Marcelo Andrade Féres al explicar que

después de la codificación de 2002, no hay espacio para la formación de disidencias. El trato del establecimiento, nítidamente inspirado por el Codice Civile, trillando el camino de la universidad de hecho. ${ }^{37}$

35 MARTINS, Fran. Curso de Direito Comercial. 30. ed. rev. atual. ampl. Rio de Janeiro: Forense, 2006. p. 414.

36 GONÇALVES NETO, Alfredo de Assis. Direito de Empresa. Comentários aos artigos 966 a 1.195 do Código Civil. São Paulo: Revista dos Tribunais, 2007, p. 568. En el original: "a distinção entre universalidade de fato e de direito estaria em que a primeira seria uma reunião de bens, como o rebanho e a biblioteca, ao passo que a segunda seria um agregado de direitos, como a herança, a massa falida etc. Na universalidade de fato o conjunto de coisas singulares, simples ou compostas, resulta da vontade da pessoa que lhes dá a destinação comum que melhor lhe aprouver. Já na universalidade de direito, há um complexo de relações de direito a que a ordem jurídica atribui caráter unitário. É nesse sentido que se devem compreender os enunciados dos arts. 90 e 91 do Código Civil de 2002. Como conjunto de bens afetados ao exercício da empresa, tal como definido no art. 1.142 do Código Civil, o estabelecimento é uma universalidade de fato."

37 FÉRES, Marcelo Andrade. Estabelecimento Empresarial: Trespasse e Efeitos 
El artículo 1.143 del Código Civil prevé que puede el establecimiento ser objeto unitario de derechos y de negocios jurídicos, translativos y constitutivos, compatibles con su naturaleza. Pues bien, el establecimiento empresarial como una "cosa" colectiva, puede tener los bienes integrantes vendidos tanto unificadamente, como en el caso del traspase, cuanto aisladamente. Al considerarse como objeto de derecho, puede ser alienado, arrestado, empeñado o hasta decomisado.

El establecimiento empresarial es compuesto por elementos materiales (corpóreos) e inmateriales (incorpóreos). Corpóreos son los bienes que tienen existencia material. Incorpóreos abarcan los bienes que no tienen existencia tangible, no ocupan espacio en el mundo físico, pues son oriundos de la inteligencia o del conocimiento humano.

No obstante, no discutiremos en este trabajo sobre las divergencias doctrinarias sobre los bienes que componen y de los que no componen el establecimiento empresarial, sino que debemos de ofrecer algunos ejemplos de bienes que pueden integrar su composición. Como incorpóreos, pueden citarse el punto comercial, la patente de invención o de modelo de utilidad, el registro del dibujo industrial, la marca, el título de establecimiento y el aviamento (good will). De bienes corpóreos muebles, son ejemplos: escaparate, vehículo, dinero, títulos, mobiliario, utensilios, equipamientos, materias primas y mercancías. En la categoría de bienes corpóreos, hay los inmuebles, pudiendo ser propiedades, edificios, construcciones y fábricas.

Los contratos no integran el establecimiento empresarial porque no son bienes, como resalta Rubens Requião ${ }^{38}$. En ese sentido, Marcelo Andrade Féres concluye que entre los bienes integrantes del establecimiento empresarial no se comprenden deudas, créditos o contratos, pues con acierto, las relaciones jurídicas integran, igualmente, el patrimonio del empresario, en el mismo patamar de los elementos del establecimiento. ${ }^{39}$

En ese sentido Ricardo Negrão explica que el patrimonio del empresario o de la sociedad empresaria se conforma por un complejo de bienes, derechos y obligaciones, siendo que el establecimiento empresarial es sólo una parte de ese patrimonio empresarial. ${ }^{40}$

Se concluye así que, desde el punto de vista jurídico, estabelecimento no se confunde com el patrimonio del empresario,

Obrigacionais. São Paulo: Saraiva, 2007, p.20. En el original: “após a codificação de 2002 , não há espaço para a formação de dissidências. $\mathrm{O}$ trato do estabelecimento, nitidamente inspirado pelo Codice Civile, trilhando o caminho da universidade de fato."

38 REQUIÃO, Rubens. Curso de Direito Comercial. São Paulo: Saraiva, 2007, p. 284.

39 FÉRES, Marcelo Andrade. Estabelecimento Empresarial: Trespasse e Efeitos Obrigacionais. São Paulo: Saraiva, 2007, p. 21.

40 NEGRÃO, Ricardo. Manual de Direito Comercial e de Empresa. São Paulo: Saraiva, 2005, p. 63. 
pero consiste em un complejo de bienes organizados para el ejercício de la actividad empresarial, por tanto, una universalidad de hecho, formada a partir de la reunion de bienes materiales e imateriales, cuya organizacion dependerá de la voluntad del empreendedor.

Una vez fijados el marco teórico y conceptual de establecimiento, se pasará al análisis sobre la posibilidad de admitir el sitio web como un establecimiento empresarial físico.

\section{EL SITIO WEB COMO UNA ESPECIE DE ESTABLECIMIENTO EMPRESARIAL SECUNDARIO (FILIAL)}

El sitio web o web que hoy se presenta como instrumento vital de la actuación empresarial, utilizado para la promoción del comercio electrónico, tiene naturaleza jurídica de establecimiento empresarial o es una extensión del establecimiento empresarial físico?

En 1988, cuando internet no presentaba el nivel de desarrollo de hoy y no era utilizada para la realización del volumen de comercio electrónico actual, Oscar Barreto Filho ${ }^{41}$ ya admitía la posibilidad "el empresario ejercer su actividad sin fijarse en punto algún".

Esa posibilidad del emprendedor de actividades económicas no fijarse en un inmueble, siempre fue posible con los comerciantes ambulantes. Pero, aún los comerciantes ambulantes, no establecidos en parte alguna, no tienen su establecimiento? Además no guardan y suministran mercancías? En el caso del emprendedor que ejerce la actividad empresarial primordialmente a través de el sitio web, las mercancías guardadas, el ordenador y el programa de ordenador, ambos utilizados para gestionar la web, son bienes que integran, en verdad, el establecimiento físico que se presenta como principal, y el sitio web es el establecimiento virtual, secundario en relación al físico, es decir, una filial de la matriz.

Tiene razón João Eunápio Borges ${ }^{42}$, al admitir que todo y cualquier emprendedor de actividad económica organizada para la producción de bienes, comercialización de bienes o la prestación de servicios, siempre tienen un establecimiento, aunque no fijado en parte física alguna (inmóvil), pues ineludiblemente hará uso de capital y trabajo. Aunque la iniciativa sea estructurada sin la presencia de una tienda física, necesitará de un ordenador, de uno o más programas de ordenador, de un servidor de internet, etc. Pero es preciso admitir

41 BARRETO FILHO, Oscar. Teoria do Estabelecimento Comercial. São Paulo: Max Limonad, 1988, p.142.

42 BORGES, João Eunápio. Curso de Direito Comercial Terrestre. Rio de Janeiro: Forense, 1971, p.184-185. 
que estos bienes pertenezcan al establecimiento físico principal, la matriz, que se considera distinto de aquella organización de la web, un verdadero establecimiento virtual.

Se sabe que internet está proporcionando una verdadera revolución en la economía y en el comercio y que como un metaterritório, desconoce las fronteras físicas, llega a cualquier lugar donde haya un ordenador conectado y por eso el empresario se relaciona con gran número de potenciales consumidores. ${ }^{43}$

Con uso del sitio web, se hace más fácil ejercer la actividad empresarial sin un establecimiento físico, pues aún sin estar presente en un espacio físico, el emprendedor contará con "las puertas abiertas" vía internet.

En 2000, Regis Magalhães Soares de Queiroz afirmó que

la revolución del comercio electrónico puede, en un futuro próximo, hacer el establecimiento empresarial muy diferente de lo que él es hoy, por lo menos en ciertas actividades y para algunos productos. Basta que pensemos en los servicios prestados online, como las páginas especializadas en búsqueda, en comparación de precios, etc. $O$ en las empresas especializadas en venta de productos directamente por la Red, tales como programas de ordenador vía download. En breve, estarán disponibles películas para download, etc.En esas hipótesis, como el producto es digital, puede ser dispensable cualquier estructura fisica de almacenamiento, administración, etc. Por eso, el establecimiento puede acabar transmigrando totalmente del mundo físico para metaterritório virtual, modificando completamente el concepto de establecimiento empresarial. Basta imaginar que la administración puede ser hecha electrónicamente, el cobro y la entrega ídem, los depósitos de la facturación en los bancos también, etc. Además de eso, la burocracia fiscal ruma rápidamente para la virtualização e imaginamos que, en breve, será posible mantener toda la escritura fiscal y contábil en la propia Internet, el pago de tributos podrá ser realizado por la Red, etc. El propio ordenador

43 QUEIROZ, Regis Magalhães Soares. Vedação da concorrência do trepassante do estabelecimento empresarial: seus limites e sua aplicação no espaço real e virtual. 185 f. Disertación (Máster en Derecho) - Faculdade de Direito, Universidade de São Paulo, São Paulo. 2000. p. 153. 
que hospeda la página puede no pertenecer a la empresa, pues el hospedaje de la web (el llamado host) puede ser terceirizada, etc. ${ }^{44}$

Pasados 13 años desde que fueron hechas esas afirmativas, débese preguntar ¿las prospecciones proyectadas por el autor ya se concretizaron?

En 2000, él admitió que no habría posibilidad de implantación del establecimiento de modo $100 \%$ virtual, aún en la hipótesis de productos y servicios que fuesen suministrados y prestados directamente vía Red. El autor informa que en aquel año de 2000, un establecimiento $100 \%$ virtual era un guión de ciencia ficción, pero que la tecnología necesaria ya estaba prácticamente disponible, faltando sólo la "informatización de la burocracia fiscal y administrativa, la diseminación del comercio electrónico y de los sistemas seguros para la transferencia de datos (criptografía, firmas electrónicas, etc.) y la adquisición de confianza por parte del público consumidor." 45

Pues, ya se está viviendo esa era. Esa tecnología ya fue implantada, sin embargo, aún perdura la duda, el emprendedor puede establecerse sin fijarse en un local físico?

Está tramitando a pasos lentos en la Cámara baja de las

44 QUEIROZ, Regis Magalhães Soares. Vedação da concorrência do trepassante do estabelecimento empresarial: seus limites e sua aplicação no espaço real e virtual. 185 f. Disertación (Máster en Derecho) - Faculdade de Direito, Universidade de São Paulo, São Paulo. 2000. p. 153-154. En el original: "a revolução do comércio eletrônico pode, em um futuro próximo, tornar o estabelecimento empresarial muito diferente do que ele é hoje, pelo menos em certas atividades e para alguns produtos. Basta pensarmos nos serviços prestados on line, como as páginas especializadas em busca, em comparação de preços, etc. Ou nas empresas especializadas em venda de produtos diretamente pela Rede, tais como programas de computador via download. Em breve, estarão disponíveis filmes para download, etc. Nessas hipóteses, como o produto é digital, pode ser dispensável qualquer estrutura física de armazenamento, administração, etc. Por isso, o estabelecimento pode acabar transmigrando totalmente do mundo físico para metaterritório virtual, modificando completamente o conceito de estabelecimento empresarial. Basta imaginar que a administração pode ser feita eletronicamente, a cobrança e a entrega idem, os depósitos do faturamento nos bancos também, etc. Além disso, a burocracia fiscal ruma rapidamente para a virtualização e imaginamos que, em breve, será possível manter toda a escritura fiscal e contábil na própria Internet, o pagamento de tributos poderá ser realizado pela Rede, etc. O próprio computador que hospeda a página pode não pertencer à empresa, pois a hospedagem do site (o chamado host) pode ser terceirizada, etc."

45 QUEIROZ, Regis Magalhães Soares. Vedação da concorrência do trepassante do estabelecimento empresarial: seus limites e sua aplicação no espaço real e virtual. 185 f. Disertación (Máster en Derecho) - Faculdade de Direito, Universidade de São Paulo, São Paulo. 2000. p. 156. 
espanõlas, el Proyecto de Ley n. 1.589/99 ${ }^{46}$ que pretende exigir la indicación del establecimiento empresarial físico para la constitución del establecimiento virtual. Si fuera aprobado este proyecto, Regis Magalhães Soares de Queiroz explica que

\begin{abstract}
tal vez no sea posible la creación de una empresa exclusivamente establecida de manera virtual, pues la alínea " $b$ "del art. 4", determina que la oferta de contratación electrónica debe informar la dirección física del establecimiento, dando a entender que esa modalidad sea necesaria para el comercio electrónico, lo que no deja de ser un factor de atraso en el desarrollo de la actividad comercial en internet, aunque su objetivo sea, claramente, lo de garantizar los derechos del consumidor, lo que podría ser contorneado, p. p.ej., con un eficiente sistema de seguros. "'47
\end{abstract}

Pero independientemente de la aprobación de este proyecto, de momento, en Brasil para crear un sitio web que ofrezca productos o servicios, se exige el suministro de la dirección física del establecimiento, pues es obligatoria la indicación de la sede del empresario individual, de la sociedad empresaria, de la sociedad simple o de la empresa individual de responsabilidad limitada, ${ }^{48}$ quienes serán los titulares de el sitio web. Pero la sede indicada pertenencia al establecimiento físico, es decir, el establecimiento principal, la matriz. El sitio web se constituye, por tanto, según la legislación brasileña como la filial.

Esa realidad aún necesita de reglamentación, pues los órganos competentes no registran el establecimiento virtual como filial, pero ni por eso podemos dejar de admitirles como un verdadero establecimiento; ya que él se presenta como un conjunto de bienes debidamente

46 Apensados: PL 104/2011 (4); PL 2367/2011; PL 3200/2012 ; PL 4189/2012 ;PL 4509/2012. 47 QUEIROZ, Regis Magalhães Soares. Vedação da concorrência do trepassante do estabelecimento empresarial: seus limites e sua aplicação no espaço real e virtual. 185 f. Disertación (Máster en Derecho) - Faculdade de Direito, Universidade de São Paulo, São Paulo. 2000. p. 156. En el original: "talvez não seja possível a criação de uma empresa exclusivamente estabelecida de maneira virtual, pois a alínea "b"do art. $4^{\circ}$, determina que a oferta de contratação eletrônica deve informar o endereço físico do estabelecimento, dando a entender que essa modalidade seja necessária para o comércio eletrônico, o que não deixa de ser um fator de atraso no desenvolvimento da atividade comercial na Internet, ainda que seu objetivo seja, claramente, o de garantir os direitos do consumidor, o que poderia ser contornado, p. ex., com um eficiente sistema de seguros."

48 Para crear una casa de campo electrónica, según las informaciones dadas pelo guía de administración de casas de campo del gobierno electrónico, es necesario para la formación de la estructura mínima que el creador indique una dirección física. Disponible en: http://epwg. governoeletronico.gov.br/guia-administracao. Acceso en: 15/abr./2014. 
organizados para el ejercicio de la actividad empresarial.

Además, en Brasil se están haciendo las gestiones necesarias para crear esa reglamentación, véase como ejemplo la Propuesta de Enmienda a la Constitución para alterar las reglas de tributación del ICMS para el comercio electrónico en el país, que ha sido aprobada en julio de 2012 por el Senado Federal. ${ }^{49}$ Por tanto, se trata de un cambio de paradigma que reconoce la autonomía del establecimiento virtual. Una vez que el ICMS es uno de los impuestos que poseen alícuotas más elevadas en el país, y está siendo concentrado en los países de origen, como ejemplo, el Estado de São Paulo concentra cerca de $40 \%$ de las compras electrónicas del país. ${ }^{50}$ El cambio tributario pretendida por la Enmienda Constitucional es que esa alícuota pueda ser más bien distribuida entre los Estados, de forma que el lugar de destino quede con la mayor parte del ICMS de las transacciones comerciales. La preocupación con la mejor reglamentación de esos tributos desrespeito al hecho de que las compras y ventas realizada por la internet están creciendo muy los últimos tiempos, significando que el comercio electrónico comienza a ser reconocido como un instrumento comercial importante y autónomo en Brasil, y consecuentemente el establecimiento virtual, que está directamente conectado al comercio electrónico. Ese cambio está demostrando que el establecimiento virtual, así como el comercio virtual, son independientes del comercio físico, necesitando así, de una reglamentación específica, ese es la comprensión.

El hecho de que, para suministrar productos o servicios vía nternet, el empresario, la sociedad empresaria y la empresa individual de responsabilidad limitada deban estar regularmente registrados en la Junta Comercial, y la sociedad simple, para ejercer actividades de arte, ciencia, literatura y profesión intelectual sin organizar elemento de empresa, deba estar regularmente registrada en la Notaría de Personas Jurídicas, en los términos del art. 45, 967, 985 y 1.150 del Código Civil de 2002, no inviabiliza la consideración del establecimiento virtual como un verdadero establecimiento empresarial, por cuanto asume la posición de filial.

Explicando mejor, la condición de filial se da porque independientemente de tratarse de empresario individual, sociedad empresaria o simple o empresa individual de responsabilidad limitada, para que la empresa esté regular y consecuentemente pueda arcar con sus impuestos es necesario que esté debidamente registrada, sea en la Junta Comercial o en el Cartório de Personas Jurídicas. Y es condición

$49 \quad$ Disponible en: http://www.istoedinheiro.com.br/noticias/89209

SENADO+APROVA+NOVA+TRIBUTACAO+PARA+COMERCIO+ELETRONICO. Acceso en: 13/02/2013.

50 Disponible en: http://convergenciadigital.uol.com.br/cgi/cgilua.exe/sys/start. htm?infoid=32871\&sid=5\#.U0823FVdVkQ. Acceso en: 15/04/2014. 
indispensable para ese registro la disponibilidad de una dirección física de la empresa. Ora, si el establecimiento virtual debe ser solamente virtual, la imprescindibilidade de la dirección no irá descaracterizar su condición de virtual e inmediatamente de establecimiento empresarial también? No! Si asumir su condición de filial. El establecimiento virtual no dejará de ser un establecimiento empresarial, pues llena los requisitos para tanto, sin embargo será una filial, para que pueda existir. $\mathrm{Y}$ es importante hacer claro que filiales son independientes entre sí.

Como los emprendedores realizarán la venta de mercancías o prestación de servicios por medio internet, ellos practicarán actividades generadoras de tributos, cuya recaudación necesariamente requiere la inscripción en el Registro Nacional de Personas Jurídicas - CNPJ, en la Hacienda provincial y en la Hacienda municipal, conforme el tipo de actividad.

Para realizar el registro en la Junta Comercial o en la Notaría de Personas Jurídicas, en el CNPJ, en la Hacienda provincial y en la Hacienda municipal, y en otros órganos, el emprendedor deberá indicar un domicilio, es decir, la sede del empresario individual, de la sociedad empresaria o simple y de la empresa individual de responsabilidad limitada. Pero la indicación de esta sede en los registros mencionados no significa que el sitio web pueda considerarse como un bien integrante del establecimiento empresarial físico.

El sitio web no se confunde con la sede indicada por el emprendedor a efectos de registro en la Junta Comercial, inscripción en el CNPJ y en las Haciendas Provincial y Municipal. El emprendedor suministra la dirección física sólo para atender a exigencia legal, pero tal circunstancia no permite concluir que el establecimiento virtual se considera como una extensión de la dirección física documentalmente indicada. Al contrario, en muchos casos, el establecimiento virtual es lo que "de hecho" existe, resumiéndose el físico al local, muchas veces a la propia residencia del negociante, donde se encuentra el ordenador y toda la parte incorpórea, también virtual, para visitar internet.

Según Maria Antonieta Lynch de Moares

web es una especie de casa virtual de una persona, empresa o institución. Técnicamente, web es un grupo de documentos HTML relacionados y archivados asociados que residen en un servidor. Web corresponde a conjunto de instrucciones ejecutadas por un ordenador que exhibe, en la tela de quien lo visita, determinadas informaciones, imágenes etc., así como, en ciertas hipótesis, permite que el 'visitante' coseche o suministre datos, solicite providencias, recoja mayores 
esclarecimientos etc. ${ }^{51}$

Tarcisio Teixeira explica que "en internet, la localización virtual es dada por un nombre de dominio, que, muchas veces, se expresa por la misma nomenclatura del título del establecimiento (físico) o por la nomenclatura de la marca." Y continúa él, diciendo que "es por la web que la actividad del empresario activo en el comercio electrónico - pasa a ser difundía y desarrollada, pues es allí que sus clientes pueden hacer compras." ${ }^{52}$

Marco Aurélio Greco divide las webs en tres categorías: (i) pasivos - que se limitan a reproducir imágenes o mensajes; es un mero vehículo de divulgación; (ii) canalizadores de mensajes - aceptan pedidos de compras de determinados bienes o servicios; (iii) inteligentes que no sólo reciben solicitudes, pero tienen condiciones técnicas de realizar operaciones más complejas, de interaccionar con el usuario. ${ }^{53}$

La doctrina nacional analizada se divide cuanto a la autonomía del sitio web y una parte lo reconoce como establecimiento empresarial y otra como una extensión del establecimiento empresarial físico.

Admitiendo que el sitio web siempre poseea una función atrelada al establecimiento físico, Thomas Henrique Junqueira de Andrade Pereira se manifiesta contra la posibilidad de web ser confundida con establecimiento empresarial o recibir la misma cualificación que este. Para él

\begin{abstract}
la web nada más es que un elemento inmaterial que compone el establecimiento, siendo que lo confundis con el establecimiento en si sería error tan grave cuanto la antigua confusión entre "establecimiento" $y$ "casa comercial". ${ }^{54}$
\end{abstract}

51 MORAES, Maria Antonieta Lynch de. Possibilidade da caracterização do site na noção de estabelecimento comercial na Lei Complementar 87/96. Revista de Direito Privado. v. 9. Enero/Marzo 2002.p. 204. En el original: "site é uma espécie de casa virtual de uma pessoa, empresa ou instituição. Tecnicamente, site é um grupo de documentos HTML relacionados e arquivados associados que residem em um servidor. Site corresponde a conjunto de instruções executadas por um computador que exibe, na tela de quem o acessa, determinadas informações, imagens etc., bem como, em certas hipóteses, permite que o 'visitante' colha ou forneça dados, solicite providências, busque maiores esclarecimentos etc."

52 TEIXEIRA, Tarcisio. Estabelecimento empresarial virtual: regime jurídico. Revista de Direito Mercantil. n. 50. v.157. jan./mar./2011. p.28.

53 GRECO, Marco Aurélio. Estabelecimento tributário e sites na internet. In: Newton De Lucca e Adalberto Simão Filho (coords.). Direito e Internet - aspectos jurídicos relevantes. 2.ed. p. pp.341-342. Apud TEIXEIRA, Tarcisio. Estabelecimento empresarial virtual: regime jurídico. Revista de Direito Mercantil. n. 50. v.157. Enero/Marzo/2011. p. 29.

54 PEREIRA, Thomaz Henrique Junqueira de Andrade. Conceito de Estabelecimento Virtual. Revista de Direito Empresarial. Curitiba: Juruá, n. 9, Enero/Junio 2008, p. 226. En el 
Thomas Henrique Junqueira de Andrade Pereira defiende la idea según la cual, el sitio web nace y permanece atrelado a un establecimiento físico, formando parte de este y que, por tanto, no hay una separación entre ellos.

Aldemario Araujo Castro también se manifiesta contrario a la posibilidad de admitir el sitio web como un establecimiento empresarial. Partiendo de la definición de establecimiento como un local, contenida en el $\S 3^{\circ}$, del art. 11, de la Ley Complementar n. 87, de 13 de septiembre de $1996^{55}$, el autor analiza las acepciones de la palabra local, y concluye no haber cualquier obstáculo a la comprensión de que la web fuera admitida como un local. Reconociendo que los aspectos de la definición legal no ofrecen mayores dificultades, concluye aún no considerarse que las webs actualmente existentes puedan necesariamente reputarse como establecimientos virtuales.

Para él, sería preciso la edición de toda una legislación regulando las peculiaridades de los establecimientos virtuales, los aspectos relacionados con el registro fiscal, procedimientos de fiscalización, solución de eventuales conflictos competencial, entre otros. ${ }^{56}$

Debemos considerar que aunque el análisis de Aldemario Araujo Castro haya sido realizada en 2000, la Ley Complementaria n. 87 por él examinada aún está en vigor, lo que lleva a concluir como válidas las conclusiones por él apuntadas, o sea, para considerarse el sitio web como establecimiento depende de reglamentación en relación a su registro como filial en los órganos competentes.

Pero la ausencia de esa reglamentación no impide concluir que el sitio web que funcione como establecimiento virtual pueda considerarse como establecimiento empresarial, pues a través de él se reúnen bienes para el ejercicio de la actividad empresarial de venta de mercancías o de prestación de servicios.

Antonia Espíndola Longoni Klee también es contraria a la idea

original: "o site nada mais é que um elemento imaterial que compõe o estabelecimento, sendo que confundi-lo com o estabelecimento em si seria erro tão grave quanto a antiga confusão entre 'estabelecimento' e 'casa comercial"”.

55 Ley Complementarn. 87/96. “Art. 11.(...). § $3^{\circ}$ Para efecto de esta Ley Complementar, establecimiento es el local, privado o público, edificado o no, propio o de tercero, donde personas físicas o jurídicas ejerzan sus actividades en carácter temporal o permanente, así como donde se encuentren almacenadas mercancías, observado, aún, el siguiente: I - en la imposibilidad de determinación del establecimiento, se considera como tal el local en que haya sido efectuada la operación o prestación, encontrada la mercancía o constatada la prestación; II - es autónomo cada establecimiento del mismo titular; III - se considera también establecimiento autónomo el vehículo usado en el comercio ambulante y en la captura de pescado; IV - responden por el crédito tributario todos los establecimientos del mismo titular."

56 CASTRO, Aldemario Araujo. Os meios eletrônicos e a tributação. 25/11/2000. Disponible en: http://www.aldemario.adv.br/meios.htm. Acceso en: 09/mar./2013. 
de sitio web como establecimiento, pues según ella

la web es un elemento inmaterial que compone el establecimiento, no se puede lo confundís con el establecimiento en sí. Lo que es virtual es el medio de acceso y no el establecimiento. Eso es, "la imaterialidade insita al establecimiento virtual no se refiere a los bienes componentes, pero a la accesibilidad". El establecimiento virtual desborda el espacio aéreo y voluble del ambiente internet operado por la web para alcanzar el propio establecimiento físico que genera toda la empresarialiedade expresa en el ámbito de la web. Es decir, la empresa en el mundo post moderno es más que la web en internet, que es su representación digital. La explotación económica de la web será objeto principal de los proveedores en el mundo post moderno que, en el mundo físico, estará debidamente materializada para poder alcanzar su fin social. La idea de que la web es la representación de una empresa en el mundo físico es sostenida por el hecho de que, si consideráramos el establecimiento integramente virtual, él acabaría esbarrando en las dificultades propias de la forma de alimentación de la web. Si por un lado él funciona y existe en el mundo virtual debidamente nominado a través de su dirección electrónica, no es menos verdad que su existencia está condicionada a los actos de gestión y administración de sus gerentes, controladores, directores, que deberán, en el mundo físico, que se organicen para la actividad empresarial en ambiente fisico para desarrollar sus actividades en internet. Es decir, en el mundo fisico deberá haber la creación de la empresa que dará soporte a las transacciones con el fin de recoger su regularidad. El establecimiento empresarial estará constituido en el mundo fisico y no en el ambiente virtual..$^{57}$

57 KLEE, Antonia Espíndola Longoni. O diálogo das fontes nos contratos pela Internet. Do vínculo contratual ao conceito de estabelecimento empresarial virtual e a proteção do consumidor. Revista de Direito do Consumidor. v. 77, 2011. p. 134-135. En el original: "o site é um elemento imaterial que compõe o estabelecimento, não se pode confundi-lo com o estabelecimento em si. O que é virtual é o meio de acesso e não o estabelecimento. Isso é, "a imaterialidade ínsita ao estabelecimento virtual não se refere aos bens componentes, mas à acessibilidade". O estabelecimento virtual extravasa o espaço aéreo e volúvel do ambiente da Internet operado pelo site para atingir o próprio estabelecimento físico que gera toda a empresarialiedade expressa no âmbito do site. Isto é, a empresa no mundo pós- 
Y continúa ella, diciendo que el sitio web es una representación del establecimiento empresarial constituido en el mundo físico. Antonia Espíndola Longoni Klee entiende que el local de donde el empresario comanda y supervisa las operaciones de la web será el local incorporado al establecimiento empresarial sobre lo cual recaerán todas las reglas jurídicas.

Hay que discordarse de tal punto de vista, en la medida en que se admite que puede haber una organización empresarial que solamente mencione una dirección física en el registro realizado ante la Junta Comercial, CNPJ, Haciendas Provincial y Municipal y otros órganos porque el ordenamiento jurídico así lo exige.

No es posible constituir regularmente una unidad empresarial sin dirección física, y razonable se muestra tal exigencia, pues es necesario saber donde físicamente encontrar el titular del establecimiento virtual para responsabilizarlo por eventuales daños y deudas originarios de la empresa, pero eso no significa que el sitio web no se consubstancie en un establecimiento empresarial. Tanto es así que el sitio web puede ser objeto de traspase. Tarcísio Teixeira concuerda con esa posibilidad al explicar que

cuando el empresario usar exclusivamente la web como forma de colocar sus productos o servicios en el mercado, el establecimiento virtual podría ser objeto de traspase, por ejemplo, en el caso de Amazon. Si fuera el caso, podría vender sólo el nombre de dominio - dirección virtual-juntamente con la marca (lo que probablemente tiene de más valioso), sin, necesariamente, vender los equipamientos que le dan soporte. ${ }^{58}$

moderno é mais do que o site na Internet, que é a sua representação digital. A exploração econômica do site será objeto principal dos fornecedores no mundo pós-moderno que, no mundo físico, estará devidamente materializada para poder atingir o seu fim social. A ideia de que o site é a representação de uma empresa no mundo físico é sustentada pelo fato de que, se considerássemos o estabelecimento integralmente virtual, ele acabaria esbarrando nas dificuldades próprias da forma de alimentação do site. Se por um lado ele funciona e existe no mundo virtual devidamente nominado através de seu endereço eletrônico, não é menos verdade que a sua existência está condicionada aos atos de gestão e administração de seus gerentes, controladores, diretores, que deverão, no mundo físico, organizarem-se para a atividade empresarial em ambiente físico para desenvolver suas atividades na Internet. Isto é, no mundo físico deverá haver a criação da empresa que dará suporte às transações com o fim de buscar a sua regularidade. O estabelecimento empresarial estará constituído no mundo físico e não no ambiente virtual."

58 TEIXEIRA, Tarcisio. Estabelecimento empresarial virtual: regime jurídico. Revista de Direito Mercantil. n. 50. v. 157. Enero/Marzo/2011. p. 31. En el original: "quando o empresário usar exclusivamente o site como forma de colocar seus produtos ou serviços no mercado, o estabelecimento virtual poderia ser objeto de trespasse, por exemplo, no caso da 
Además, es preciso reconocer que el proveedor de productos o servicios puede constituir una matriz y varias filias, todos ellos físicos. El establecimiento físico principal, y los varios otros establecimientos físicos secundarios (filiales, agencias o sucursales) son independientes entre sí y todos reunidos integran el patrimonio empresarial. Claro que los secundarios dependen de la existencia del establecimiento principal para que también existieran, pero no dejan de encuadrarse como establecimiento empresarial en los términos de la definición legal prevista en el art. 1.142, del Código Civil de 2002 por el hecho de haber esa dependencia.

El mismo raciocinio puede desarrollarse con relación al sitio web, que puede depender de actos de gestión y administración practicados en un lugar físico, pero tal circunstancia no le retira la condición de complejo de bienes reunidos para el ejercicio de la actividad empresarial. Los establecimientos empresariales secundarios también dependen de la práctica de actos de gestión y administración realizados en el establecimiento principal.

En ese sentido, es la opinión de Tarcísio Teixeira al examinar la tercera especie de web presentada por Marco Aurélio Greco. Para él, las webs del tipo pasivo y del tipo canalizador de mensajes no pueden ser consideradas establecimientos empresariales propiamente dichas. Pero la web inteligente es admitida por él como un establecimiento empresarial, pues "guarda semejanza con las funciones del establecimiento físico, lo que permite el desarrollo de la actividad empresarial, en especial vender sus productos y servicios a la clientela." 59

De igual manera señala Maria Antonieta Lynch de Moraes, para quién "ni todo web se reviste de las características de un establecimiento empresarial." ${ }^{60}$ Y para ella, tanto la web canalizadora de mensaje cuanto la inteligente son suscetíveis de clasificarse como establecimientos empresariales virtuales. ${ }^{61}$

Kleber Luiz Zanchim admite que la web poseea la misma naturaleza jurídica del establecimiento físico, sólo diferenciándose en relación a aspectos relativos a la forma de acceso en que se insertan:

Amazon. Se fosse o caso, poderia vender apenas o nome de domínio - endereço virtual -, juntamente com a marca (o que provavelmente tem de mais valioso), sem, necessariamente, vender os equipamentos que lhe dão suporte)."

59 TEIXEIRA, Tarcisio. Estabelecimento empresarial virtual: regime jurídico. Revista de Direito Mercantil. n. 50. v.157. Enero/Marzo/2011, p. 29-30.

60 MORAES, Maria Antonieta Lynch de. Possibilidade da caracterização do site na noção de estabelecimento comercial na Lei Complementar 87/96. Revista de Direito Privado. v. 9. Enero/marz/ 2002.p. 210.

61 MORAES, Maria Antonieta Lynch de. Possibilidade da caracterização do site na noção de estabelecimento comercial na Lei Complementar 87/96. Revista de Direito Privado. v. 9. Enero/Marzo/2002.p. 211. 
el establecimiento empresarial es 'todo complejo de bienes organizado, para el ejercicio de la empresa, por el empresario o por la sociedad empresaria', así, el establecimiento comercial virtual es compuesto por este complejo de bienes, aunque inmateriales en su mayoría, difiriéndose del establecimiento tradicional por la imaterialidade insita a la su accesibilidad, pues mientras aquel es accesible por medio del desplazamiento en el espacio, este se hace por un click. Así, son ambos (el establecimiento virtual y el establecimiento físico) una única realidad jurídica, poseyendo idéntica naturaleza jurídica, y encuadrándose en la misma categoría de establecimiento comercial del art. 1.142 del Código Civil brasileño, difiriendo, sólo, en algunos aspectos secundarios que se presentan propios de los medios en que se insertan. ${ }^{62}$

En el mismo sentido, se encuentra la posición de Fábio Ulhoa Coelho. Para él, la única distinción entre el establecimiento físico y el virtual se refiere a la forma de acceso de los consumidores y adquirentes interesados en los productos, servicios o virtualidades que el empresario ofrece al mercado. ${ }^{63}$ Para él

el tipo de acceso al establecimiento empresarial define la clasificación de este. Cuando hecho por desplazamiento en el espacio, es físico; cuando por transmisión y recepción electrónica de datos, virtual. Hay aspectos comunes a los dos tipos de establecimiento, como el fondo de empresa, pero hay derechos referentes al establecimiento físico que no existen relativamente al virtual, como lo de

62 ZANCHIM, Kleber Luiz. A forma dos negócios jurídicos no direito das sucessões. Revista de Direito Privado. São Paulo: Ed. Revista dos Tribunais, 2008. En el original: “o estabelecimento empresarial é 'todo complexo de bens organizado, para o exercício da empresa, pelo empresário ou pela sociedade empresária', assim, o estabelecimento comercial virtual é composto por este complexo de bens, ainda que imateriais em sua maioria, diferindo-se do estabelecimento tradicional pela imaterialidade ínsita à sua acessibilidade, pois enquanto aquele é acessível por meio do deslocamento no espaço, este se faz por um click. Assim, são ambos (o estabelecimento virtual e o estabelecimento físico) uma única realidade jurídica, possuindo idêntica natureza jurídica, e enquadrando-se na mesma categoria de estabelecimento comercial do art. 1.142 do Código Civil brasileiro, diferindo, apenas, em alguns aspectos secundários que se apresentam próprios dos meios em que se inserem."

63 COELHO, Fábio Ulhoa. Curso de direito comercial. v. 3. São Paulo: Saraiva, 2012. p. 50. 
renovación compulsória de la locación. ${ }^{64}$

Para él, la imaterialidade inherente al establecimiento virtual no se refiere a los bienes componentes que son materiales o no en cualquier establecimiento, físico o virtual. La imaterialidade del establecimiento virtual se refiere a la accesibilidad. Por la forma de acceso ser inmaterial, el autor concluye que no es posible admitir la existencia de punto comercial y el derecho a la renovación compulsória del contrato de alquiler, en virtud de la explotación del punto. ${ }^{65}$

También es de la misma opinión, Marlon Tomazette, que reconoce en el establecimiento virtual o digital, un verdadero establecimiento empresarial, solamente no se aplican a él las reglas de este a aquel, en lo que se refiere al punto y a la acción renovatória.

El empresario al practicar la actividad empresarial por medio del sitio web, no crea una irrealidade, un campo de ficción, imaginario o fantasioso, por realizarla en medio incorpóreo o sin territorio físico.

Están de acuerdo Fábio Ulhoa Coelho y con Marlon Tomazette cuando admiten el sitio web como establecimiento empresarial, suscetíveis de reglamentación por las mismas normas relativas al establecimiento físico.

Pero, es preciso discordar de los referidos autores cuando afirman que los bienes materiales forman parte del establecimiento virtual. Por el raciocinio desarrollado en el presente trabajo, siendo internet un metaterritório y no siendo posible constituir establecimiento virtual sin constituir un establecimiento físico (aunque muy simple), no se puede admitir que los bienes materiales formarán parte del establecimiento virtual, lo que por su parte, no tiene el propósito de descaracterizarlos como un verdadero establecimiento empresarial.

De ese modo, se concluye que el sitio web se considera como establecimiento empresarial, situado en el espacio cibernético. Aunque carezca de presencia tangible, es real y existe de hecho, lo que se demuestra por las actividades del empresario, quien pacta una infinitud de negocios jurídicos tan reales cuanto eficaces a través del complejo de bienes que produce efectos sociales, económicos y jurídicos en dimensión material.

64 COELHO, Fábio Ulhoa. Curso de direito comercial. v. 3. São Paulo: Saraiva, 2012. p.50. En el original: "o tipo de acesso ao estabelecimento empresarial define a classificação deste. Quando feito por deslocamento no espaço, é físico; quando por transmissão e recepção eletrônica de dados, virtual. Há aspectos comuns aos dois tipos de estabelecimento, como o fundo de empresa, mas há direitos referentes ao estabelecimento físico que não existem relativamente ao virtual, como o de renovação compulsória da locação."

65 COELHO, Fábio Ulhoa. Curso de direito comercial. v. 3. São Paulo: Saraiva, 2012. p. 50-51. 


\section{CONCLUSIÓN}

En el desarrollo de este trabajo, se verificó la posibilidad de concebir internet como un espacio calificado por no ser físico, como una enorme red de ordenadores y aún como un metaterritório que trasciende el territorio físico donde es posible ser disponibilizada todo tipo de información, que inclusive permite la realización de incontables negocios jurídicos que presuponen el concepto de comercio electrónico.

Partiendo de esa concepción del internet como metaterritório y de la teoría que admite el establecimiento empresarial como una universalidad de hecho, sin dejar de analizar las condiciones legales exigidas para el ejercicio regular de la actividad económica, en especial, la empresarial, se concluyó que el sitio web - cuando creado para el ejercicio de la actividad de compraventa y venta de mercancías o la prestación de servicios o las dos actividades - presenta las mismas características del establecimiento empresarial reglamentado por el art. 1.142 y siguientes del Código Civil de 2002.

Se llegó a tal conclusión porque se estimó que él, aunque virtual, es una universalidad de hecho, que consiste en una reunión de bienes especialmente organizados por el empresario o por la sociedad empresaria para el ejercicio de la actividad empresarial.

El hecho de haber - para montar una web - la necesidad de informar la sede del empresario o de la sociedad empresaria en el registro realizado ante la Junta Comercial, en la inscripción ante el CNPJ, la Receta Provincial y la Municipal, no aleja la autonomía del sitio web, no le retira la condición de establecimiento empresarial.

Se verificó, es verdad, que hay necesidad de alteración legislativa que permita el registro del establecimiento virtual como un establecimiento secundario, es decir, como una filial, pero fue filtrado también que el ordenamiento jurídico brasileño está en vías de recoger ese ajuste legal, y un buen ejemplo es la Propuesta de Enmienda a la Constitución que altera las reglas de tributación del ICMS para el comercio electrónico en el país, para admitir que la mayor parte del impuesto sea pagada a la unidad federativa donde es entregue la mercancía.

El sitio web depende de la existencia de la sede tanto cuanto las filiales físicas dependen de la existencia de la matriz y el hecho de él ser tan real cuanto a aquellas, reuniendo los bienes necesarios para el ejercicio de la empresa, possibilita quitar la conclusión de que se consubstancia en un establecimiento secundario en relación a la matriz, o sea, el sitio web o establecimiento virtual es una filial. 
BAPTISTA, Luiz Olavo. Comércio Eletrônico: Uma Visão do Direito Brasileiro, Revista da Faculdade de Direito da Universidade de São Paulo. V.94, São Paulo: Serviço Técnico de Imprensa da Faculdade de Direito da Universidade de São Paulo, 1999.

BARRETO FILHO, Oscar. Teoria do Estabelecimento Comercial. São Paulo: Max Limonad, 1988.

BERTOLDI, Marcelo M. RIBEIRO, Marcia Carla Pereira. Curso avançado de Direito Comercial. 6. ed. rev. atual. São Paulo: Revista dos Tribunais, 2011.

BORGES, João Eunápio. Curso de Direito Comercial Terrestre. Rio de Janeiro: Forense, 1971.

CAMPINHO, Sérgio. $O$ direito de empresa à luz do novo Código Civil. 5. ed. ampl. atual. Rio de Janeiro: Renovar, 2005.

CANELLA, Sergio Eduardo; LEWIS, Sandra Barbon. Breves anotações sobre o comércio eletrônico. v. 9. Londrina: Scientia Iuris, 2005.

CASTRO, Aldemario Araujo. Os meios eletrônicos e a tributação. Disponible en: http://www.aldemario.adv.br/meios.htm. Acceso en: 09/03/2013.

COELHO, Fábio Ulhoa. Manual de Direito Comercial. 17a ed. São Paulo: Saraiva, 2006.

Saraiva, 2012. . Curso de direito comercial. v. 1. São Paulo:

Saraiva, 2012. Curso de direito comercial. v. 3. São Paulo:

FÉRES, Marcelo Andrade. Estabelecimento Empresarial: Trespasse e Efeitos Obrigacionais. São Paulo: Saraiva, 2007.

FLORESS, Cristian. História da Internet. Disponível em: https:// sites.google.com/site/historiasobreossitesdebusca/historia-da-internet. Acesso em: 19/12/2012.

GONÇALVES NETO, Alfredo de Assis. Direito de Empresa. Comentários aos artigos 966 a 1.195 do Código Civil. São Paulo: Revista dos Tribunais, 2007.

HOUAISS, Antônio. Dicionário Eletrônico Houaiss da Língua Portuguesa. Rio de Janeiro: FL Gama Design Ltda Editora Objetiva, 2009.

IKEDA. Quem somos. Disponible en: <http://www.ikeda.com.br// quem-e-ikeda/>. Acceso en: 24/jun./2012.

KLEE, Antonia Espíndola Longoni. O diálogo das fontes nos contratos pela Internet. Do vínculo contratual ao conceito de estabelecimento empresarial virtual e a proteção do consumidor. Revista de Direito do Consumidor. v. 77. 2011, p. 134-135.

LÉVY, Pierre. Cibercultura. São Paulo:Editora 34, 2000. 
MALOSÁ JÚNIOR, Francisco Carlos. A realidade virtual como elemento transformador de estabelecimento empresarial. Anales de lo XVII Encontro Nacional do Conpedi. Salvador: Boiteux, Junio/2008. p.1194-1213.

MARTINS, Fran. Curso de Direito Comercial. 30. ed. rev. atual. ampl. Rio de Janeiro: Forense, 2006. p. 414.

MORAES, Maria Antonieta Lynch de. Possibilidade da caracterização do site na noção de estabelecimento comercial na Lei Complementar 87/96. Revista de Direito Privado. v. 9. Enero/Marzo 2002.p. 204.

NEGRÃO, Ricardo. Manual de Direito Comercial e de Empresa. São Paulo: Saraiva, 2005.

PEREIRA, Thomaz Henrique Junqueira de Andrade. Conceito de Estabelecimento Virtual. Revista de Direito Empresarial. Curitiba: Juruá, n. 9, Enero/Junio2008.

QUEIROZ, Regis Magalhães Soares. Vedação da concorrência do trepassante do estabelecimento empresarial: seus limites e sua aplicação no espaço real e virtual. $185 \mathrm{f}$. Dissertação (Mestrado em Direito) - Faculdade de Direito, Universidade de São Paulo, São Paulo. 2000.

REQUIÃO, Rubens. Curso de Direito Comercial. São Paulo: Saraiva, 2007.

ROHRMANN, Carlos Alberto. O Direito Comercial Virtual - A Assinatura Digital. Revista da Faculdade de Direito Milton Campos. Belo Horizonte: Del Rey, v.4, 1997.p. 35-51.

TATSCH, Fabiano. Discussão: HTTP. Disponible en: http://pt.wikipedia. org/wiki/Usu\%C3\%A1rio:Fabiano_Tatsch/Arquivo_3 Acceso en: 26 de febrero de 2013.

TEIXEIRA, Tarcisio. Estabelecimento empresarial virtual: regime jurídico. Revista de Direito Mercantil. n. 50. v.157. Enero/Marzo 2011. p.27-33.

ZANCHIM, Kleber Luiz. A forma dos negócios jurídicos no direito das sucessões. Revista de Direito Privado. São Paulo: Revista dos Tribunais, v. 35, Julio/Septiembre 2008. 